\title{
Estrogen receptor beta in prostate cancer: friend or foe?
}

\author{
Adam W Nelson ${ }^{1,2}$, Wayne D Tilley ${ }^{1,3}$, David E Neal ${ }^{1,2,4}$ and Jason S Carroll ${ }^{1,4}$ \\ ${ }^{1}$ Cancer Research UK, Cambridge Institute, University of Cambridge, Robinson Way, Cambridge CB2 ORE, UK \\ ${ }^{2}$ Department of Urology, Addenbrooke's Hospital, Cambridge University Hospitals NHS Foundation Trust, \\ Cambridge CB2 0QQ, UK \\ ${ }^{3}$ Dame Roma Mitchell Cancer Research Laboratories, Faculty of Health Sciences, School of Medicine, The University \\ of Adelaide, Level 4, Hanson Institute Building, DX Number 650 801, Adelaide, South Australia 5000, Australia \\ ${ }^{4}$ Department of Oncology, University of Cambridge, Cambridge CB2 2QQ, UK
}

Correspondence should be addressed to A W Nelson Email

adam.nelson@cruk.cam.ac.uk

\begin{abstract}
Prostate cancer is the commonest, non-cutaneous cancer in men. At present, there is no cure for the advanced, castration-resistant form of the disease. Estrogen has been shown to be important in prostate carcinogenesis, with evidence resulting from epidemiological, cancer cell line, human tissue and animal studies. The prostate expresses both estrogen receptor alpha (ERA) and estrogen receptor beta (ERB). Most evidence suggests that ERA mediates the harmful effects of estrogen in the prostate, whereas ERB is tumour suppressive, but trials of ERB-selective agents have not translated into improved clinical outcomes. The role of ERB in the prostate remains unclear and there is increasing evidence that isoforms of ERB may be oncogenic. Detailed study of ERB and ERB isoforms in the prostate is required to establish their cell-specific roles, in order to determine if therapies can be directed towards ERB-dependent pathways. In this review, we summarise evidence on the role of ERB in prostate cancer and highlight areas for future research.
\end{abstract}

Key Words

- estrogen receptor beta

- prostate

- cancer

- androgen

- estrogen

\section{Introduction}

Prostate cancer is the commonest, non-cutaneous cancer in men, affecting 214 per 1000 European men. It is the second commonest cause of cancer death, accounting for $15 \%$ of all male cancers in developed countries (Heidenreich et al. 2011, Mottet et al. 2011). Ever since the landmark research of Huggins and Hodges (Huggins 1943, Huggins \& Hodges 1972) demonstrating the importance of steroid hormones in the development and treatment of prostate cancer, there has been interest in the effects of estrogen on the prostate gland. Initially, hormone treatment for prostate cancer involved manipulation of systemic hormone levels with exogenous estrogen therapy (in the form of high-dose diethylstilbestrol) to suppress androgen production indirectly via the hypothalamo-pituitary-gonadal axis (Huggins \& Hodges 1972). However, the unacceptably

http://erc.endocrinology-journals.org DOI: 10.1530/ERC-13-0508
(C) 2014 Society for Endocrinology Published by Bioscientifica Ltd. Printed in Great Britain high rates of cardiovascular side effects associated with systemic estrogen therapy, coupled with the advent of alternative treatment options, resulted in reduced use of this therapy (Morales \& Pujari 1975). Consequently, for a period of time, interest in understanding the effects of estrogen in the prostate also declined. Hormonal suppression of prostate cancer is now primarily achieved with androgen deprivation therapy (ADT) involving synthetic leutinising-hormone-releasing-hormone (LHRH) analogues, which suppress androgen production via negative feedback inhibition of the hypothalamicpituitary-gonadal axis (Heidenreich et al. 2011). Although most prostate tumours initially respond well to ADT, after a period of time prostate cancer inevitably ceases to respond to androgen deprivation. Disease progression with ADT is

This paper is one of 12 papers that form part of a thematic review section on Androgens and the AR in Breast and Prostate Cancer. The Guest Editors for this section were Wayne Tilley and Frank Claessens. WV Jilley was pot involved in the handling of $: 19: 46 \mathrm{AM}$ this paper, on which he is listed as an author. via free access 
termed castration-resistant prostate cancer (CRPC) (Scher et al. 2004), and is characterised by altered androgen receptor (AR) signalling. Possible mechanisms for this include amplification (Bubendorf et al. 1999) or mutation of the AR gene, stabilisation of AR protein (Holzbeierlein et al. 2004), altered expression of AR-coregulators (Chmelar et al. 2007), generation of constitutively active AR splice variants (Dehm et al. 2008, Hu et al. 2012) and increased intratumoural androgen biosynthesis (Cai \& Balk 2011, Ishizaki et al. 2013), all of which contribute to the maintenance of AR-dependent transcription in a castrate environment (Knudsen \& Penning 2010). Genome-wide mapping of AR DNA-binding has shown that in CRPC AR binds to new sites on the DNA, resulting in an alternative transcriptional programme to that seen in primary disease (Sharma et al. 2013). CRPC carries a poor prognosis and a median survival of 18 months from diagnosis (Wu et al. 2007). New generation chemotherapeutics agents targeting AR signalling such as abiraterone and enzalutamide have led to modest improvement in prostate cancer survival, but they are not curative (Attard et al. 2011, Lamb et al. 2013).

In recent years, with advances in the understanding of $\mathrm{AR}$ function in CRPC and the cross-talk that occurs between AR and estrogen receptor alpha (ERA) in prostate cancer (Grubisha \& Defranco 2013) and specific subtypes of breast cancer (Robinson et al. 2011), there has been renewed interest in understanding ER biology in the prostate and its role in prostate cancer. Further interest has arisen as a result of recent phase 2 clinic trial evidence supporting the use of transdermal estrogen therapy in prostate cancer, which avoids first-pass liver metabolism and has an improved side-effect profile over both parenteral estrogens and LHRH analogues (Langley et al. 2013). It is now known that the prostate gland expresses both ERA and estrogen receptor beta (ERB) (Horvath et al. 2001, Celhay et al. 2010). ERB is expressed in a wide range of reproductive and non-reproductive tissues including the CNS, cardiovascular system, gastrointestinal tract, urogenital tract (male and female) and skeleton (Bottner et al. 2014). The physiological role of ERB in each of these tissues has not been fully elucidated, but it has been implicated in the regulation of glucose homeostasis and insulin signalling and may also modulate immunologically mediated inflammatory pathways (Harris et al. 2003, Foryst-Ludwig et al. 2008). In addition, ERB is considered a negative regulator of ERA, acting to modulate transcriptional responses to estrogen in a tissue- and cell-context dependent manner (Bottner et al. 2014).
The traditional paradigm regarding the roles of the two ERs in the prostate is that ERB is predominantly protective, being anti-carcinogenic and pro-apoptotic (Chang \& Prins 1999, Horvath et al. 2001, Zhu et al. 2004, Ellem \& Risbridger 2007, McPherson et al. 2010, Muthusamy et al. 2011, Nakajima et al. 2011, Attia \& Ederveen 2012), whereas ERA is oncogenic and promotes cell proliferation and survival (Ellem \& Risbridger 2007, Risbridger et al. 2007, McPherson et al. 2008, Bonkhoff \& Berges 2009, Celhay et al. 2010, Attia \& Ederveen 2012). This view is based on a range of observations including epidemiological and in vivo studies, preclinical drug trials and expression profiles of the two ERs in human prostate cancer. However, much of the published data regarding the role and function of ERB appear to be conflicting, with studies conducted in cancer cell lines (McPherson et al. 2010, Dey et al. 2012, Yang et al. 2012), rodent models (Ricke et al. 2008, Attia \& Ederveen 2012) or human tissues (Horvath et al. 2001, Celhay et al. 2010, Leung et al. 2010, Hussain et al. 2012) generating apparently contradictory results. Thus the precise actions of ERB in the prostate remain to be completely elucidated (Shaaban et al. 2003, Risbridger et al. 2007, Zhao et al. 2007, Celhay et al. 2010, Nelles et al. 2011, Dey et al. 2012, Yang et al. 2012). In this article, we review recent research in the area of ERB biology, with particular attention to its relevance in clinical aspects of human prostate cancer, and highlight areas for future research.

\section{Evidence for the role of estrogen in prostate cancer: epidemiological}

It is well established that European men have a lower risk of developing prostate cancer than African-American men, and that for Japanese men the lifetime risk of developing prostate cancer is lower still (de Jong et al. 1991, Ross et al. 1992, Ellem \& Risbridger 2007). Two interesting observations are noteworthy in this respect. First, there are no significant differences in levels of circulating testosterone between these three ethnic groups (Ross et al. 1992), whereas levels of serum estrogens are higher in black men as compared with Caucasian men (Rohrmann et al. 2007, Abd Elmageed et al. 2013). However, a direct correlation between serum estrogen levels and prostate cancer risk has not been demonstrated (Yao et al. 2011, Bosland 2013). Secondly, the age of peak prostate cancer incidence occurs at a time when serum testosterone levels are in decline, but estrogen levels remain constant (Vermeulen et al. 2002). This has lead to the hypothesis that it is the ratio of serum estrogen to

Published by Bioscientifica Ltd. 
testosterone, rather than the absolute values of each, which gives rise to the observed differences in prostate cancer risk between the various ethnic groups (Ellem \& Risbridger 2007, Bosland 2013). However, recent technological advances, which now permit more accurate measurement of both ultra-low and intra-tissue hormone levels, mean that a contemporary reassessment of this subject is needed (Barth et al. 2010, Hickey \& Norman 2010, Stener-Victorin et al. 2010). Determining the actual levels of estrogen and androgen metabolites in the prostate will be essential for understanding ERA, ERB and AR behaviour. Racial differences in levels of prostatic ERB expression as measured by immunohistochemistry have been demonstrated by Abd Elmageed et al. (2013) who showed that the frequency of ERB immunostaining in prostate tumours was significantly higher in black men than in Caucasian men, which in turn, correlated with poorer clinical outcome.

Estrogen-related prostate cancer risk has been linked to dietary factors (Hori et al. 2011). The traditional Japanese diet contains high levels of dietary phytoestrogens, which have been shown in prostate cancer cell lines to upregulate ERB activity resulting in decreased expression of AR (Thelen et al. 2005, 2007, Stettner et al. 2007) and induction of G1-cell cycle block (Shen et al. 2000). In rat models, phytoestrogens can induce prostate epithelial cell apoptosis (Attia \& Ederveen 2012), thereby demonstrating protective effects against prostate cancer. Phytoestrogens, along with other dietary estrogens such as lignans, flavonoids and lipoflavinoid are known to have up to 30-fold greater affinity for ERB than ERA, and are thought to promote the beneficial, protective effects of estrogen in the prostate (Kuiper et al. 1998, Ellem \& Risbridger 2007, Thelen et al. 2014). A large populationbased case-control study from Sweden demonstrated a reduced incidence of prostate cancer in those with a diet rich in phytoestrogens (Hedelin et al. 2006). Incidence of prostate cancer in Japan has been rising since the 1940s, coinciding with increased 'westernisation' of the Japanese diet. Specifically, it has been proposed that the 20-fold increase in the consumption of milk and animal fat, both of which contain estrogens with a high affinity for ERA (mediating the adverse effects of estrogen) may explain some of the recent rise in prostate cancer incidence among Japanese men (Ganmaa et al. 2003, Carruba 2007). There are, however, conflicting results in the literature regarding the effects of phytoestrogens in prostate cancer, as genistein (a highly ERB-specific isoflavone (Jiang et al. 2013)) has been shown in a study of prostate cancer xenograft-bearing mice to promote the development of metastatic disease progression in an ERB-dependent manner (Nakamura et al. 2013) (discussed further in section 'Evidence for the role of estrogen in prostate cancer: drug trials').

\section{Evidence for the role of estrogen in prostate cancer: animal studies}

Some of the most compelling evidence for the importance of estrogen in prostate carcinogenesis comes from a series of animal studies (Ricke et al. 2008) (Fig. 1). Ricke et al. demonstrated in mice that androgen, estrogen, aromatase and ERA are all required for prostate carcinogenesis. Aromatase is a highly substrate-specific cytochrome p450 enzyme, found in the membrane of the endoplasmic reticulum, which has the unique function in vertebrates of being able to convert androgens to estrogens (Ghosh $\mathrm{et} \mathrm{al}$. 2009). In normal prostate, aromatase is expressed in the stromal cells and is responsible for local paracrine conversion of androgen to estrogen (Risbridger et al. 2007).

The necessity for estrogen in prostate carcinogenesis was demonstrated in experiments where either androgen alone, or androgen and estrogen were administered to aromatase knockout (ArKO) mice (Ricke et al. 2008). ArKO mice given androgen and estrogen developed prostatic intraepithelial neoplasia (PIN - a premalignant histological phenotype which, especially when high grade or multifocal, is a recognised risk factor for the development of invasive prostate cancer (Nelson et al. 2003, Merrimen et al. 2009)), whereas ArKO mice given androgen alone had no such change (Ricke et al. 2008). From this, the authors concluded that local production of estrogen within the prostate, facilitated by aromatase-mediated conversion of androgen to estrogen, was likely to be

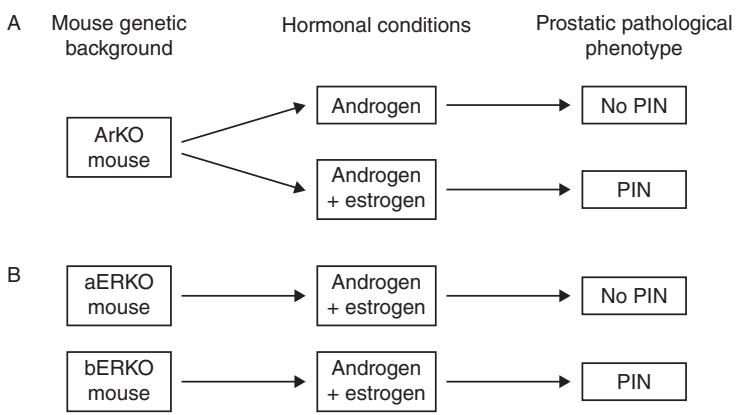

\section{Figure 1}

Summary of animal studies conducted by Ricke et al. (2008), demonstrating: (A) in order for prostate intraepithelial neoplasia (PIN) to arise it is necessary for androgen, estrogen and functional aromatase all to be present; (B) this is an ERA-mediated process, which is suppressed by ERB. ArKO, aromatase knockout; aERKO, ERA knockout; bERKO, ERB knockout.

Published by Bioscientifica Ltd. 
a significant factor in prostate carcinogenesis. Epithelial expression of aromatase is upregulated in prostate cancer (Ellem et al. 2004, Celhay et al. 2010), a process that is driven by gene promoters (I.3, I.4 and PII) responsive to inflammatory cytokines (Santen et al. 1997, Zhao et al. 1997, Shozu et al. 2000). The implication of this is twofold; first, increased local production of estrogens with resulting carcinogenesis and, secondly, the establishment of a 'positive feedback loop' between aromatase, estrogen and tissue inflammation (Ellem \& Risbridger 2007). Indeed, high expression levels of aromatase and aromatase gene polymorphisms in early onset primary human prostate cancer have been found to correlate with decreased time to disease relapse, further underlining its importance in prostate carcinogenesis (Cussenot et al. 2007, Celhay et al. 2010).

In order to determine which of the ERs is responsible for mediating adverse effects of estrogen, Ricke et al. (2008) administered testosterone and estrogen to ERB knockout (bERKO) or ERA knockout (aERKO) mice. There was no difference between wild type (WT) and bERKO mice receiving hormone treatment, whereas aERKO mice did not develop PIN, suggesting that ERA mediated this particular adverse effect of estrogen in the prostate (Ricke et al. 2008). Similar studies in intact rats demonstrated that testosterone alone is insufficient for the development of PIN; it was only with the addition of the selective ERA agonist, ERA-45, that PIN developed (ERA-45 is reported to have a 286-fold greater affinity for ERA than ERB (Attia \& Ederveen 2012)). However, with the administration of testosterone, ERA-45 and an ERB-selective agonist (ERB26), the onset of PIN was prevented (Attia \& Ederveen 2012), demonstrating the differential function of the two ERs in prostate carcinogenesis. These findings must be interpreted with some caution due to the ongoing debate in the field regarding the phenotypic variability and validity of the bERKO mouse models used in previous studies (Harris 2007).

\section{Evidence for the role of estrogen in prostate cancer: drug trials}

ERs are attractive targets for prostate cancer treatment as therapeutic agents are already in existence and are widely used in hormone-dependent breast cancer (Lumachi et al. 2011). Raloxifene, a selective ER modulator (SERM), has been shown to induce cellular apoptosis and nuclear fragmentation in both androgen-sensitive and androgenindependent prostate cancer cell lines through activation of ERB, suppression of ERA and subsequent induction of the caspase-8 and -9 pathways (Kim et al. 2002a,b, Rossi et al.
2011). Studies of selective ERB agonists on prostate cancer cell lines have also been encouraging. Several investigators have demonstrated that selective ERB agonists will induce cystic atrophy in basal cells of the prostatic epithelium (McPherson et al. 2010, Hussain et al. 2012). These basal cells do not express AR (Ruizeveld de Winter et al. 1991), and therefore, are unaffected by conventional ADT. Thus, once ADT is withdrawn, the prostatic epithelium is able to regenerate from this basal cell population. Administration of an ERB agonist, however, perturbs this regenerative process resulting in cellular apoptosis via the extrinsic pathway, mediated by tumour necrosis factor $\alpha$ (TNFA). This, importantly, is an androgen-independent process and may therefore be relevant to the treatment of CRPC (McPherson et al. 2010, Hussain et al. 2012). Recent research has shown that ERB-mediated cellular apoptosis may also occur through the intrinsic pathway, via upregulation of the Forkhead protein, FOXO3a, which itself is regulated by PTEN. Deletion mutations of PTEN result in inhibition of the apoptotic mechanism of FoxO3a, providing a possible ERB-mediated mechanism by which PTEN mutations in prostate cancer contribute to cancer growth (Dey et al. 2013b).

In vitro studies of the effects of dietary phytoestrogens on prostate cancer cell lines have shown conflicting results. On the one hand it has been shown that administration of ERB-selective phytoestrogens in CRPC will revert cancer cells to a less malignant phenotype (Wuttke et al. 2002, Messina 2010, Andres et al. 2011, Reiter et al. 2011). This may be due to a number of mechanisms. It is known that mutated forms of $\mathrm{AR}$ are upregulated in CRPC allowing AR to continue driving prostate cancer growth and progression in the absence of androgen (Scher et al. 2004, Waltering et al. 2012). Upregulation of ERB in response to phytoestrogens results in down-regulation of $\mathrm{AR}$, with a subsequent decline in serum levels of prostate-specific antigen (PSA) and other AR-dependent genes (Thelen et al. 2005, 2007). ERB may therefore function as a negative regulator of AR, as well as ERA. However, as previously mentioned, in a study conducted using a patient-derived prostate cancer tissue line mouse xenograft model (maintained by serial transplantation of sub-renal capsule xenografts) (Andersen et al. 2010), the ERB-selective phytoestrogen genistein has been shown to promote development of metastatic disease (Nakamura et al. 2013). The explanation for these conflicting results is not presently clear; however it has been hypothesised that in the mouse xenograft tumours, increased expression of metallothionein proteins in response to genistein-induced ERB activity

Published by Bioscientifica Ltd. 
may contribute to tumour invasion and metastasis (Nakamura et al. 2013); an interaction, which may not be reflected in cell-line studies where the tumour microenvironment is absent.

A promising clinical study was published by Price $e t a l$. (2006). In a phase $2 \mathrm{~b}$ clinical trial of 514 men with biopsyproven high-grade PIN, toremifene, an ERA-selective antagonist (Kangas 1990), was shown to reduce the incidence of invasive prostate cancer at 12 months by $48 \%$ vs placebo, thus preventing $6.8 \%$ cancers per 100 men per year. However, the outcome of this trial was reported after only a 12-month study period and no long-term data on the use of toremifene in prostate cancer have since been generated to address potential long-term side effects or duration of treatment benefit.

Trials of other ER modulators have also been unsuccessful. Fulvestrant, an ERA antagonist, has been shown to be effective in preclinical models with growth inhibition of prostate cancer cell lines (Lau et al. 2000, Leung et al. 2006a). However, in a phase 2 study of 20 men with CRPC, fulvestrant failed to produce either a clinical or biochemical (PSA) response (Chadha et al. 2008). Similarly, tamoxifen, a mixed ERA agonist/antagonist has been shown to be ineffective in men with CRPC (Bergan et al. 1999) despite inhibiting the growth of prostate cancer cell lines in preclinical studies (Rohlff et al. 1998). The reasons underlying these observations are not presently clear; however, it is likely that prostate cancer cell lines used in the preclinical studies are not reflecting the complex cross-talk between AR, ERA and ERB, and other stromal-epithelial interactions known to occur in vivo (Hanahan \& Weinberg 2011, Robinson et al. 2011, Grubisha \& Defranco 2013, Madak-Erdogan et al. 2013). These studies highlight the critical need for improved preclinical models of prostate cancer, in which to test new therapeutic agents targeted to the ERs.

\section{ERs in the prostate}

ERB was first identified by Kuiper et al. (1996) in the rat prostate. In humans, it is a $55 \mathrm{kDa}$ protein encoded by the ESR2 gene located on chromosome 14 (Enmark et al. 1997). Expression of ERB is regulated epigenetically by a CpG island in the promotor region (Zhu et al. 2004) and ERB expression is silenced by DNA-hypermethylation of the promotor (Zhao et al. 2003, Rody et al. 2005). ERB is strongly expressed in the basal and secretory compartments of benign prostate epithelium in both rodents and humans (Horvath et al. 2001). The principle ligand of ERB in the prostate is $5 \alpha$-androstane- $3 \beta, 17 \beta$-diol ( $3 \beta$-diol), a metabolite of $5 \alpha$-dihydrotestosterone (DHT) (Oliveira et al. 2007). In prostate cell lines (benign and cancer) ERB has been shown to maintain differentiation of epithelial cells by regulation of epithelial-mesenchymal transition (EMT) genes such as Twist via hypoxia-inducible factor 1 alpha (HIF-1A) (Mak et al. 2013).

The gene coding human ERA (ESR1) is located on chromosome 6 (Menasce et al. 1993). In the prostate (rodent and human) ERA is predominantly expressed in the stroma (Celhay et al. 2010, Attia \& Ederveen 2012). In utero studies of prostate development in rodents have shown that ERA expression appears before ERB, and excessive estrogenisation of the developing prostate (mediated via ERA) results in permanent changes in the prostate including squamous metaplasia, inflammation and epithelial dysplasia (Arai et al. 1978, Prins \& Birch 1997). This 'imprinting' results in increased risk of a premalignant phenotype and prostate carcinogenesis (Prins et al. 2006, 2007, McPherson et al. 2008, Prins \& Korach 2008). Although expressed from different genes, ERA and ERB share substantial sequence homology, in particular the DNA-binding domains (DBD) of the two receptors are $97 \%$ identical. This allows both ERs to recognise a consensus estrogen response element (ERE) on DNA with equal affinity (Le et al. 2013).

The advent of genome-wide transcription factor mapping by chromatin immunoprecipitation coupled with high-throughput sequencing (ChIP-seq) has enabled detailed study of how transcription factors such as steroid hormone receptors function, by revealing the locations of their DNA-binding sites (Carroll et al. 2006). We now know, for example, that in addition to proximal gene promotors, ERA and AR bind to distal enhancer elements, far from gene-transcription start sites, and by recruitment of co-regulatory factors initiate gene transcription by longrange chromatin interactions (Carroll et al. 2005, Wang et al. 2007, Massie et al. 2011). For ERA and AR, a number of these co-regulatory factors are now well-characterised and represent potential therapeutic targets (Carroll et al. 2005, Wang et al. 2007, 2009, 2011, Hurtado et al. 2011, Robinson et al. 2011, Sahu et al. 2011). Genome-wide mapping of both tagged (Zhao et al. 2010) and forceexpressed recombinant ERB (Madak-Erdogan et al. 2013) DNA-binding in the MCF7 breast cancer cell line has demonstrated significant overlap between ERA and ERB DNA-binding sites, inferring complex cross-talk between the two receptors. In addition, there is evidence that ERB binds to distal enhancer elements in the same manner as ERA and AR to regulate gene expression (Carroll et al. 2005, Zhao et al. 2010, Massie et al. 2011). Despite these

Published by Bioscientifica Ltd. 
significant insights, there is still very limited understanding of the mechanisms and co-regulators by which ERB activity may be modulated and thus the resulting effects on ERB transcription.

\section{ER expression in prostate cancer}

In normal prostate, ERA expression is confined to the prostatic stroma (Tilley et al. 1985, Wernert et al. 1988, Leav et al. 2001). In contrast to ERB, ERA mRNA has been detected in high-grade PIN of the prostate, and ERA expression is upregulated in prostatic epithelium of intermediate- and high-grade tumours and in CRPC (Bonkhoff \& Berges 2009, Celhay et al. 2010, Nelles et al. 2011). Stromal ERA expression and elevated expression of aromatase have been shown to be independent predictors of shorter time to relapse in CRPC (Celhay et al. 2010). Expression of the TMPRSS2-ERG fusion gene, which has been suggested to be a marker of an aggressive tumour phenotype found in up to 50\% of prostate cancer (Qu et al. 2013, Razzak 2013), increased in the NCI-H660 prostate cancer cell line following treatment with an ERA agonist (Setlur et al. 2008). NCI-H660 is an AR-negative prostate cancer cell line expressing the TMPRSS2-ERG fusion gene (Mertz et al. 2007), derived from the lymph node metastasis of a small-cell prostate tumour with neuroendocrine differentiation (Johnson et al. 1989, Lai et al. 1995). Expression of ERA and aromatase with the R264C polymorphism has been shown to result in shorter progression-free survival and an increased risk of developing CRPC in a study of 115 men treated with docetaxel (Sissung et al. 2011). Taken together, these observations support the hypothesis that ERA can act as an oncogene by mediating the adverse effects of estrogen in the prostate.

Declining levels of ERB have been observed with progression from benign prostatic hyperplasia to malignant disease (Horvath et al. 2001), with a further decrease associated with increasing Gleason grade of prostate cancer (Leav et al. 2001, Asgari \& Morakabati 2011, Attia \& Ederveen 2012, Dey et al. 2013b). ERB expression is low in high-grade PIN of the prostate (Risbridger et al. 2007), reflecting its pre-malignant phenotype. It has been shown that as ERB expression declines with the development of prostate cancer, levels of HIF-1A increase, resulting in epithelial dedifferentiation and growth of high-grade, aggressive tumours (Mak et al. 2013).

Horvath et al. (2001) showed in a study of 159 prostates obtained by radical prostatectomy that over $75 \%$ of tumours in their cohort did not express ERB. However, in low-grade (Gleason 3) tumours, ERB expression was maintained, and correlated positively with disease-free survival (Horvath et al. 2001). In an additional finding that seems to contradict these results, where ERB expression was maintained, there was a higher rate of disease relapse irrespective of tumour grade (Horvath et al. 2001). Other studies have demonstrated high ERB expression in bone and lymph node metastases (Zhu et al. 2004, Bouchal et al. 2011). A recent study has shown that the combination of ERB expression and AR phosphorylation in hormone-naïve prostate cancer correlates with poor clinical outcome (Zellweger et al. 2013). In that study, increased expression of WT ERB (ERB1) was associated with higher Gleason grade and greater proliferative activity. Fifty percent of the patients in the study cohort showed a significant increase in ERB expression with subsequent development of CRPC (Zellweger et al. 2013).

The variability of ERB expression in differing grades and stages of prostate cancer presents some difficulty in deciphering the underlying mechanisms and role of ERB in prostate carcinogenesis. If ERB is tumour-suppressive, then it is logical that its expression declines with advancing carcinogenesis. However, this does not explain why ERB expression is then high in lymph node or bone metastases ( Zhu et al. 2004, Bouchal et al. 2011), or the observed correlation between high ERB expression and poor prostate cancer prognosis (Horvath et al. 2001, Zellweger et al. 2013). This may be due to varying levels of promotor methylation throughout the carcinogenic process introducing reversible, stage- and tissue-specific changes in ERB expression and altering its transcriptional role (Risbridger et al. 2007, Cotrim et al. 2013). In addition, it has been proposed that ERB expression may confer a selective advantage for subclones of prostate cancer cells to metastasise (Zhu et al. 2004), resulting in the maintenance of ERB expression in metastatic deposits. A further possible explanation for this discrepancy is variability in the specificity and sensitivity of commercially available ERB antibodies (Skliris et al. 2002, Hartman et al. 2012). Different ERB antibodies have been shown to only be suitable for particular experimental applications (Weitsman et al. 2006), creating some difficulty in the interpretation of results from different studies.

More recently, there is increasing evidence that expression of the ERB isoform, ERB2, is increased in highgrade and metastatic prostate cancer (Dey et al. 2012). ERB2 may act as an oncogene and has been implicated specifically in the process of cancer metastasis (Chen et al. 2009, Leung et al. 2010, Dey et al. 2012). If the antibodies used in the abovementioned studies (Horvath et al. 2001,

Published by Bioscientifica Ltd. 
Zhu et al. 2004, Bouchal et al. 2011, Zellweger et al. 2013) are in fact detecting ERB2, rather than ERB1, some of the abovementioned contradictions may be explained. Further detailed study is required to answer this definitively.

\section{The role of ERB isoforms}

At least five splice variants of ERB have been identified (Leung et al. 2006b) (Fig. 2). Expression of ERB3 is limited to the testis (Moore et al. 1998), but ERB1, ERB2, ERB4 and ERB5 are known to be expressed in the prostate, and there is increasing evidence indicating that ERB2 in particular acts as an oncogene in direct opposition to ERB1 (Chen et al. 2009). ERB1 is composed of eight exons, the first six of which are common to the five isoforms. The isoforms share the same first four functional domains with ERB1 (including the DBD), but the LBD differs (Moore et al. 1998, Hanstein et al. 1999, Leung et al. 2010). ERB2 and ERB5 have been studied in detail in prostate cancer and shown to correlate with poor prognosis (Leung et al. 2010, Dey et al. 2012). Specifically, co-expression of nuclear ERB2 and cytoplasmic ERB5 was shown in a study of 144 patients with long-term follow up to be an independent prognostic marker for biochemical relapse, postoperative metastasis and time to metastasis following radical prostatectomy for localised prostate cancer (Leung et al. 2010). While ERB2 is the dominant isoform in prostate cancer, its mechanism of action remains unclear as it lacks the LBD. ERB2 seems to act as a transcriptional repressor of ERB1, thus disabling the usual, protective effect of ERB1 (Cotrim et al. 2013). One hypothesis proposed by Leung et al. $(2006 b)$ is that whilst ERB1 functions as a homodimer, ERB isoforms function only when heterodimerised with ERB1. These ERB heterodimers form preferentially under the influence of oestradiol (E2) and have higher transcriptional activity than the ERB1 homodimer. Interestingly, phytoestrogens such as genistein promote formation of the ERB1 homodimer. As ERB2 lacks a LBD, it is proposed that when it is heterodimerised with ERB1, transcription is inhibited. In this model, ERB2 may therefore function as a dominant-negative regulator of ERB1 activity. This may explain one way that ERB transcription can be modulated in cell- and tissue-specific contexts (Leung et al. 2006b, Cotrim et al. 2013).

In ovarian carcinoma, levels of ERB5 mRNA are elevated, compared with benign tissues, suggesting it has an oncogenic role in that particular context (Suzuki et al. 2008). A study of stable tetracycline-inducible ERB2expressing MCF7 breast cancer cells has suggested that ERB2 can also heterodimerise with ERA to induce ERA degradation and inhibition of ERA transcription (Zhao et al. 2007).

The influence of ERB2 in both prostate and breast cancer metastasis is thought to result from regulation of genes responsible for EMT (Leung et al. 2010, Dey et al. 2012, Roy et al. 2012, Yang et al. 2012). EMT is a marker of early oncological change, which enables cancer cells to

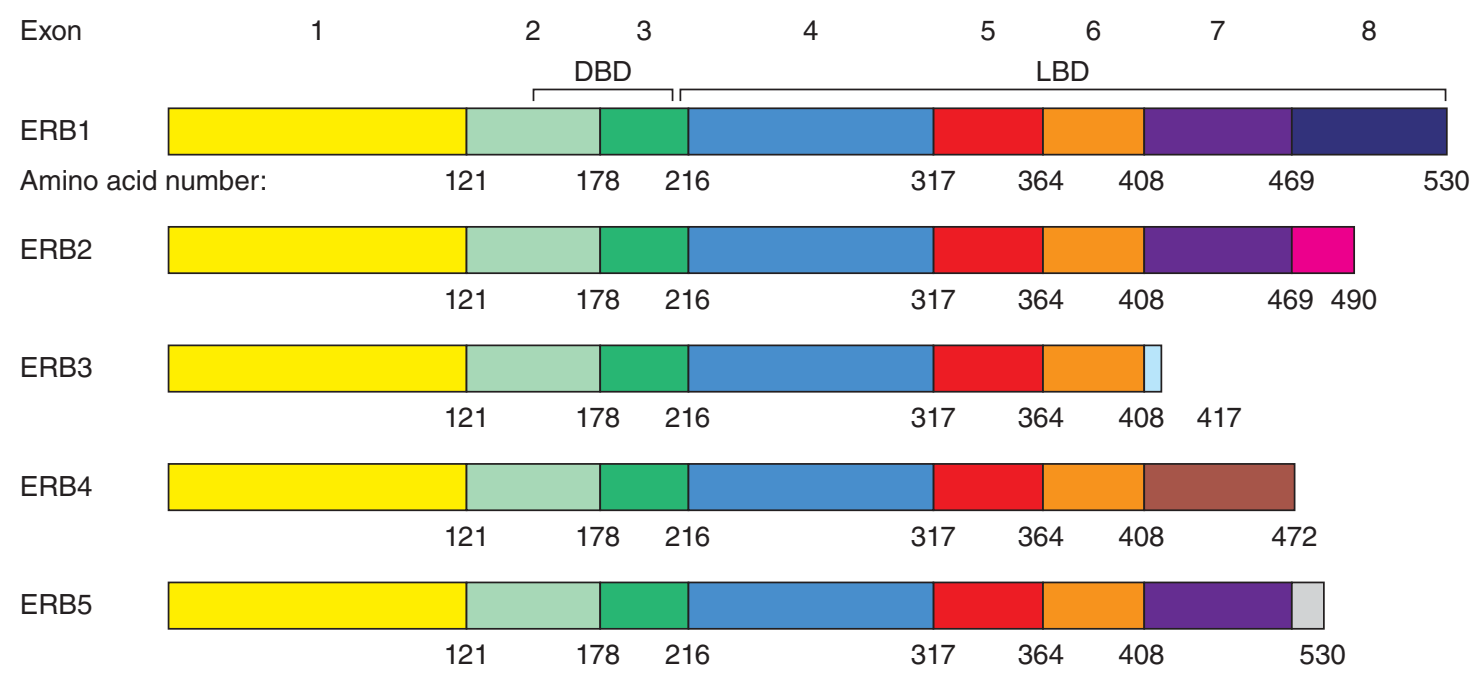

Figure 2

Schematic showing the structure of ERB isoforms. ERB1 (WT) contains eight exons, the first six of which are common to the other isoforms. All five isoforms share common DNA-binding domains (DBD), but the ligand-binding domains (LBD) differ. Data from Uniprot (http://www. uniprot.org/) and ClustalW2 (http://www.ebi.ac.uk/Tools/msa/clustalw2/).

Published by Bioscientifica Ltd. 
invade surrounding tissues and eventually metastasise to distant sites (Hanahan \& Weinberg 2011). Although well-characterised in vitro, there is still some controversy as to whether the EMT programme occurs in vivo or is an artefact of cell line studies, principally because of difficulties differentiating transformed epithelial cells from the surrounding tumour stromal tissue, and the fact that metastatic deposits often closely resemble the epithelial tissue of origin (Hollier et al. 2009). Nevertheless, evidence is emerging that EMT markers can be observed in circulating tumour cells, suggesting that it does occur in vivo (Li et al. 2013).

In a study conducted in prostate cancer cell lines, expression of ERB2 was shown to result in upregulation of the EMT genes TWIST1 (which correlates with high-grade prostate cancer) and RUNX2 (normally repressed by ERB1) (Dey et al. 2012). This interaction between ERB2 and EMT genes is facilitated by a proto-oncogene, PELP1, which interacts with a number of steroid hormone receptors including ERA (Vadlamudi et al. 2001), ERB and AR (Yang et al. 2012). In breast cancer, PELP1 has been shown to interact with histones to remodel chromatin and modulate expression of key EMT genes such as TWIST1, SNAIL and ZEB (Roy et al. 2012). It is therefore possible that PELP1 and ERB2 have a role in the promotion of prostate cancer metastasis. If correct, this hypothesis could explain the previously discussed findings of high ERB expression in bone and lymph node metastases, and the correlation between persistent ERB expression in highgrade prostate cancer and greater risk of disease relapse (Horvath et al. 2001, Zhu et al. 2004, Bouchal et al. 2011, Zellweger et al. 2013). This is an important area for further investigation.

\section{The role of ER-mediated inflammation in mechanisms of cancer progression}

Inflammation is a well-established process in the development and progression of cancer (Hanahan \& Weinberg 2011) (Fig. 3). Several inflammatory mechanisms, centering on ER function, have been implicated in the development and progression of prostate cancer. Loss of E-cadherin is a well-established marker of EMT, with associated loss of cell adhesion and a resulting increase in cell motility (Guarino et al. 2007, Grubisha \& Defranco 2013). ERB has been shown to be a negative regulator of inflammatory processes (Harris et al. 2003) and in the prostate its expression is known to correlate with E-cadherin levels. One hypothesis is that as ERB expression declines during the progression from benign to low-grade,

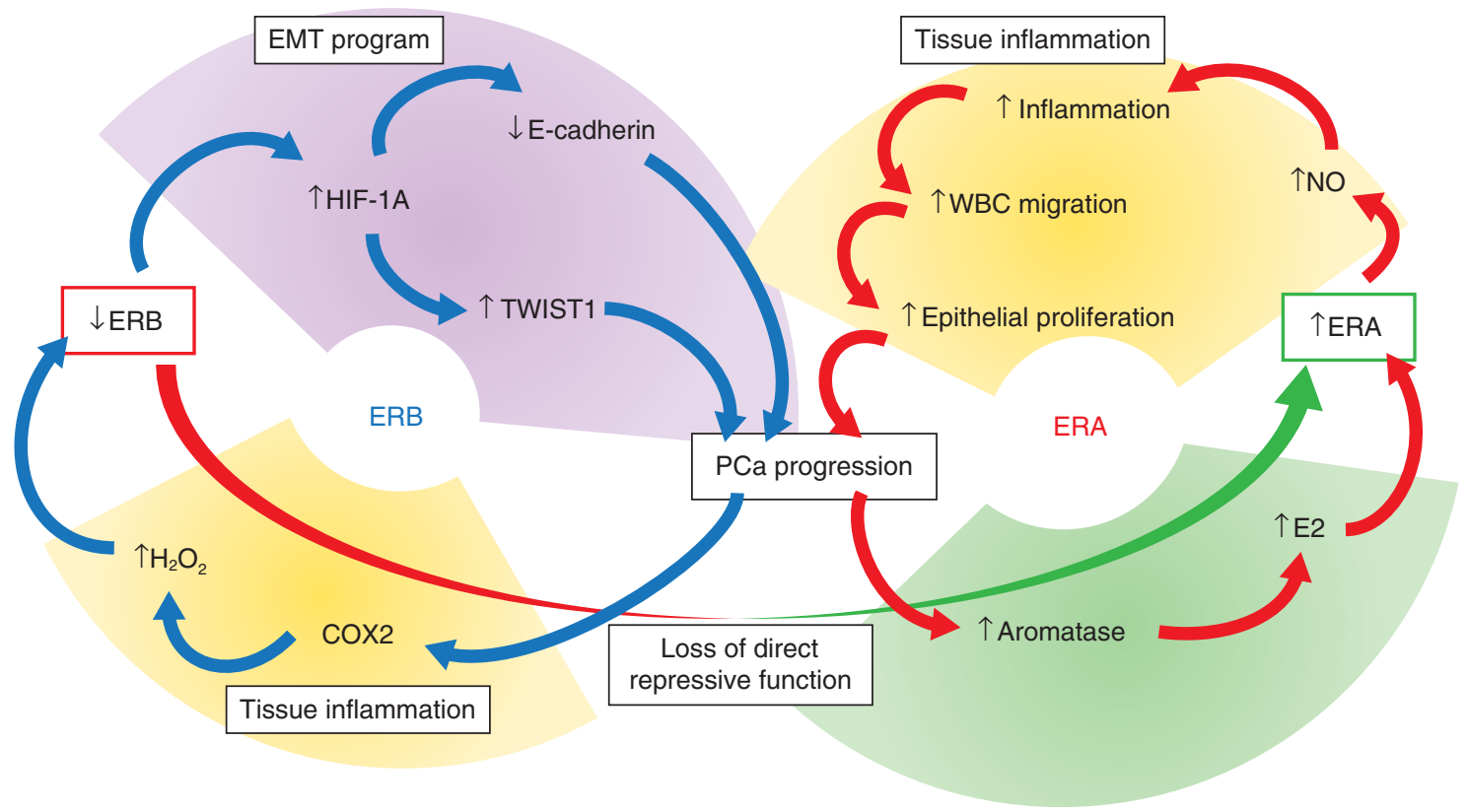

Figure 3

Proinflammatory positive feedback loops in prostate cancer progression, centering on ERB and ERA function. In response to tissue inflammation, decreased ERB expression results in upregulation of EMT programme genes leading to prostate cancer metastasis. Tissue inflammation leads to increased aromatase expression and increased inflammatory-cell epithelial infiltration. Decreased ERB transcription results in loss of direct repression of ERA. WBC, white blood cell; E2, oestradiol; NO, nitric oxide; $\mathrm{H}_{2} \mathrm{O}_{2}$, hydrogen peroxide; $\mathrm{COX} 2$, cyclo-oxygenase-2; $\mathrm{PCa}$, prostate cancer. 
to high-grade cancer (Leav et al. 2001, Celhay et al. 2010, Asgari \& Morakabati 2011), the resulting decline in E-cadherin leads to an increased propensity to develop metastatic disease. ERB transcriptional activity is sensitive to oxidation resulting from tissue inflammatory processes and a local paracrine signalling network (Grubisha et al. 2012). When ERB is oxidised by $\mathrm{H}_{2} \mathrm{O}_{2}$ and other reactive oxygen species, DNA binding is lost and expression of E-cadherin is reduced. The pro-inflammatory enzyme COX2, expressed by prostatic stroma, generates sufficient $\mathrm{H}_{2} \mathrm{O}_{2}$ to inactivate ERB. As COX2 is overexpressed in prostate cancer, a pro-inflammatory positive feedback loop is established (Grubisha \& Defranco 2013).

ERA and aromatase also play a critical role in tissue inflammation in prostate cancer and expression of these two factors in tumour cells is an independent predictor of time to biochemical relapse (defined as two consecutive rises in serum PSA) in men treated with ADT (Celhay et al. 2010). In prostate cancer, expression of aromatase is increased, particularly in epithelial cells resulting in increased levels of intraprostatic estrogen, which acts via ERA to promote tissue inflammation via local generation of nitric oxide (Pinzone et al. 2004, Ellem \& Risbridger 2007, Risbridger et al. 2007, Celhay et al. 2010, Nelles et al . 2011). Pro-inflammatory mediators such as TNFA and prostaglandin $\mathrm{E}_{2}$ in turn upregulate CYP19 expression, resulting in increased aromatase activity (Subbaramaiah et al. 2011). Thus an additional pro-inflammatory positive feedback loop centering on ERA function is established (Ellem \& Risbridger 2007). Evidence of neutrophil and leucocyte migration from the stroma to the epithelium in mouse models confirms the presence of this inflammatory process (Bianco et al. 2002, 2006). Inflammatory cytokines released by the migrating immune cells result in abnormal proliferation of prostate epithelium and increase the risk of further premalignant change (Bianco et al. 2006).

\section{A change in perspective: an oncogenic role for ERB?}

ERB1 has been implicated directly as an oncogene (Yang et al. 2012). In that study, ERB1-mediated, non-androgenic AR signalling was demonstrated in several prostate cancer cell lines in hormone-deplete (castrate) conditions (Fig. 4). In the presence of DHT, AR binds to androgen-responsive elements (AREs) on DNA to initiate AR-dependent transcription. In these conditions, ERB1 and PELP1 form a complex in the nucleus. However, in the absence of DHT and with addition of E2, the ERB1-PELP1 complex binds

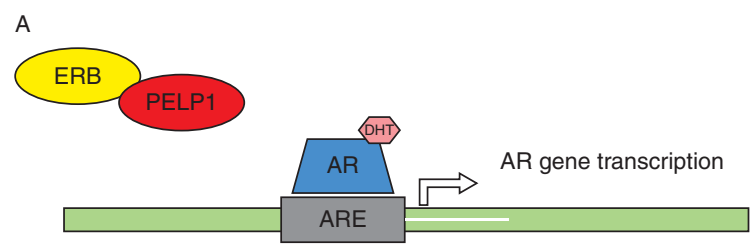

B

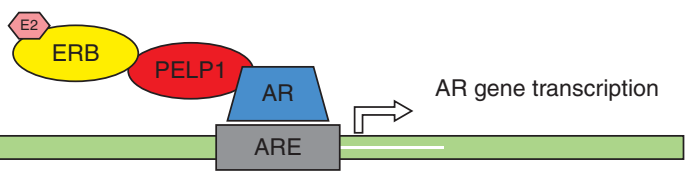

Figure 4

A hypothesis of non-androgenic, ERB-mediated transcription of AR-dependent genes via interaction with PELP1, as proposed by Yang et al. (2012). (A) In the presence of DHT ERB-PELP1 forms a complex, which does not bind to AR. (B) In the absence of DHT, and with oestradiol (E2) treatment, the ERB-PELP1-AR complex binds to the androgen-responsive element (ARE) to initiate AR-dependent gene transcription.

Figure adapted from Yang L, Ravindranathan P, Ramanan M, Kapur P, Hammes SR, Hsieh JT \& Raj GV 2012 Central role for PELP1 in nonandrogenic activation of the androgen receptor in prostate cancer. Molecular Endocrinology 26 550-561.

to AR (with PELP1 acting as a bridge between the two nuclear receptors) and is recruited to an ARE, resulting in the transcription of AR-dependent genes. This ERB1PELP1-AR complex was shown to facilitate cellular proliferation in response to E2 treatment, demonstrating a clear mechanism by which estrogens might continue to drive prostate cancer growth and progression in the castrate environment, thereby highlighting the potential oncogenic role of ERB1. Furthermore, it has been proposed that ERB1 may have a role in mediating the 'switch' from hormone-sensitive prostate cancer to CRPC (Zellweger et al. 2013). It may be that ERB is only tumour-suppressive in early stages of the disease until, by means of a currently unknown mechanism, it subsequently becomes an oncogene. This is an important question for detailed investigation, as therapeutic silencing of such a 'switch' could theoretically reduce the risk of developing CRPC.

Our understanding of the role of ERB in the development and progression of prostate cancer is evolving, but there are many unresolved issues. Given the divergent activity of ERB isoforms and the potential for an oncogenic role for ERB1 (Yang et al. 2012), we can no longer hold to the classical paradigm of estrogen signalling in the prostate, which surmises that ERA is tumour promoting and ERB is tumour suppressive. In order to progress our understanding of estrogen biology in cancer it is critical that the mechanisms underlying the differential functions of ERA, ERB and the various ERB isoforms are elucidated in detail (Madak-Erdogan et al. 2013). Recent advances in

Published by Bioscientifica Ltd. 
understanding the function of the two ERs at the genomic level have been beginning to provide insights into this complex area. Madak-Erdogan et al. (2013) used ChIP-seq to demonstrate the genome-wide chromatin binding profiles and differing transcriptional responses of ERA or ERB in the MCF7 breast cancer cell line. Their data confirmed the previous finding using the tagged ERB ChIP-seq approach (Zhao et al. 2010) demonstrating significant overlap between the binding sites of ERA and ERB. Specifically, when each of the receptors was present alone, there was a $40 \%$ overlap between ERA and ERB DNA-binding sites. However, when co-expressed, the number of binding sites available for each ER dropped by $\sim 50 \%$. This suggests a complex mechanism where each ER restricts the total number of binding sites available to the other, but when the activity of one ER is reduced, chromatin binding by the other is increased. While the functional consequences of altered ERA and ERB chromatin binding in these different contexts remain to be fully elucidated, the proliferative effects of estrogen acting via ERA were reduced with the co-expression of ERB. When expressed in isolation, ERA regulates cell cycle genes, helping push cells from growth-arrested states into DNA synthesis and subsequent mitosis. However, when ERB is co-expressed, ERA's ability to respond to ligand is reduced and cell proliferation decreases. ERB's anti-proliferative function was demonstrated to occur through direct binding to apoptosis and cell-cycle regulation genes (Madak-Erdogan et al. 2013). Similar results were demonstrated by Le et al. (2013) in ChIP-seq of MCF7/C4-12 cells (derivative of MCF7 with no ERA expression) transfected to stably express ERB. These data support the previously discussed hypothesis that ERB is tumour-suppressive and a negative regulator of ERA, functioning in a variable manner according to the particular cellular context (Zhao et al. 2010, Bottner et al. 2014, Cotrim et al. 2013). However, as these data were generated using breast cancer cell lines, it is important that the hypothesis is further tested in appropriate prostate cancer models. The isoform specificities of the antibodies used in the ChIP-seq study
(Madak-Erdogan et al. 2013) are unknown and therefore it is not clear how these findings in MCF7 cells are applicable to the previously discussed differential functions of ERB isoforms (Leung et al. 2010, Dey et al. 2012). Clearly, there is an urgent need to develop specific antibodies to ERB and its isoforms to address these questions (Haldosen et al. 2014).

\section{Conclusions}

Despite a number of promising preclinical studies showing efficacy of ERB-selective agents in prostate cancer (Kim et al. 2002a,b, McPherson et al. 2010), there is currently no evidence of clinical benefit from the use of these treatments in terms of disease-specific or overall survival. The underlying reasons for this necessitate further investigation. One possibility is insufficient dosing of the therapeutic agents in question (Chadha et al. 2008). Most of the preclinical studies of ERB-selective agents and much of our current knowledge of ERB biology results from studies conducted in various prostate cancer cell lines. The expression profiles of the nuclear receptors AR, ERA and ERB vary between each of the commonly used cell lines and different authors report contrasting results in individual cell lines (Table 1) (Veldscholte et al. 1990, Kim et al. 2002b, Holbeck et al. 2010, Nakajima et al. 2011). None of these commonly used cell lines are entirely representative of human tissue, as exemplified by the fact that in the human prostate ERA expression is predominantly stromal, whereas luminal epithelial cells express ERB and AR, and basal epithelial cells only express ERB (Ruizeveld de Winter et al. 1991, Bonkhoff \& Berges 2009). Cell line models, therefore, cannot reproduce the stromal-epithelial interactions known to be important in cancer development and progression (Hanahan \& Weinberg 2011), or the complex interplay that has been observed between ERA and ERB, and how transcription from activation of one receptor impacts the availability of DNA-binding sites to the other (Madak-Erdogan et al. 2013). Studies conducted in ex vivo

Table 1 Variability of reported nuclear receptor expression in commonly used prostate cancer cell lines

References
Veldscholte et al. (1990) and
Kim et al. $(2002 a, b)$
Nakajima et al. $(2011)$
Holbeck et al. (2010)
Holbeck et al. (2010) and
Nakajima et al. (2011)

http://erc.endocrinology-journals.org DOI: 10.1530/ERC-13-0508

\begin{tabular}{l} 
Cell line \\
\hline LNCaP \\
DU145 \\
DU145 \\
PC3
\end{tabular}

AR
Positive
Negativ
Neg

(C) 2014 Society for Endocrinology Printed in Great Britain
Published by Bioscientifica Ltd. 
primary human tissue culture (Centenera et al. 2012) or xenografts of human tumours (Lawrence et al. 2013) may be helpful in this regard.

Estrogen-related pathways are clearly of great importance in the development and progression of hormonedependent cancers such as prostate cancer, but the role of ERB remains controversial, with numerous contradictions in the published literature. Our current understanding of ER biology in the prostate is insufficient to facilitate precise manipulation of the molecular machinery in a meaningful fashion (Abd Elmageed et al. 2013). Recent developments in the understanding of apparently opposing ERB isoforms (Leung et al. 2010) and the mechanisms governing ERB transcription are beginning to provide greater insights into ERB biology with implications not just for prostate cancer but also for colon, breast and ovarian cancers (Suzuki et al. 2008, Chantzi et al. 2013, Dey et al. 2013a). In order to determine whether ERB represents a useful therapeutic target in prostate cancer, and more specifically in CRPC, it is vital that these mechanisms are fully elucidated. Given that ERA and ERB can homo- or heterodimerise with ERB isoforms, the cross-reactivity between different estrogenic ligands, the differing effects of ERB in specific cellular contexts, and the fact that ERA and ERB can recognise the same DNA-binding sites and interact with common co-regulators, this is likely to be a difficult task (Shaaban et al. 2003, Zhao et al. 2010, Cotrim et al. 2013, Le et al. 2013, Madak-Erdogan et al. 2013). The challenge will be to identify and characterise the ERA- and ERB-unique DNA-binding sites, and furthermore, to define the ERB isoform-specific DNA binding sites in order to determine their respective functions. To improve outcomes for patients, there is an urgent need for detailed understanding of the mechanisms governing the differential functions of the two ERs in tissue- and disease-specific contexts as well as investigation of novel therapeutic agents that selectively target ERA- and ERB-dependent pathways.

\section{Declaration of interest}

The authors declare that there is no conflict of interest that could be perceived as prejudicing the impartiality of the review.

\section{Funding}

A W Nelson is supported by The Medical Research Council (MR/L00156X/1) and The Urology Foundation Scholarship (RESCH1302); W D Tilley is supported by grants from the National Health and Medical Research Council of Australia (ID 627185), Cancer Australia (ID 627229) and the Prostate Cancer Foundation of Australia; D E Neal is supported by Cancer Research UK, The Medical Research Council and The National Institute for
Health Research; J S Carroll is supported by an ERC starting grant and an EMBO Young investigator award.

\section{Author contribution statement}

A W Nelson and W D Tilley conceptualised and designed the structure of the article. A W Nelson conducted the literature review. A W Nelson and W D Tilley co-wrote the manuscript. D E Neal and J S Carroll provided critical review and revision of the manuscript.

\section{Acknowledgements}

A W Nelson is an Honorary Research Training Fellow of the Royal College of Surgeons of England/Prostate Cancer UK and acknowledges their support.

\section{References}

Abd Elmageed ZY, Moroz K, Srivastav SK, Fang Z, Crawford BE, Moparty K, Thomas R \& Abdel-Mageed AB 2013 High circulating estrogens and selective expression of ER $\beta$ in prostate tumors: implications for racial disparity of prostate cancer. Carcinogenesis 34 2017-23. (doi:10.1093/ carcin/bgt156)

Andersen RJ, Mawji NR, Wang J, Wang G, Haile S, Myung JK, Watt K, Tam T, Yang YC, Banuelos CA et al. 2010 Regression of castrate-recurrent prostate cancer by a small-molecule inhibitor of the amino-terminus domain of the androgen receptor. Cancer Cell 17 535-546. (doi:10.1016/ j.ccr.2010.04.027)

Andres S, Abraham K, Appel KE \& Lampen A 2011 Risks and benefits of dietary isoflavones for cancer. Critical Reviews in Toxicology 41 463-506. (doi:10.3109/10408444.2010.541900)

Arai Y, Chen CY \& Nishizuka Y 1978 Cancer development in male reproductive tract in rats given diethylstilbestrol at neonatal age. Gann 69 861-862.

Asgari M \& Morakabati A 2011 Estrogen receptor $\beta$ expression in prostate adenocarcinoma. Diagnostic Pathology 6 61. (doi:10.1186/1746-1596-6-61)

Attard G, Richards J \& de Bono JS 2011 New strategies in metastatic prostate cancer: targeting the androgen receptor signaling pathway. Clinical Cancer Research 17 1649-1657. (doi:10.1158/1078-0432.CCR-10-0567)

Attia DM \& Ederveen AG 2012 Opposing roles of ER $\alpha$ and ER $\beta$ in the genesis and progression of adenocarcinoma in the rat ventral prostate. Prostate 72 1013-1022. (doi:10.1002/pros.21507)

Barth JH, Field HP, Yasmin E \& Balen AH 2010 Defining hyperandrogenism in polycystic ovary syndrome: measurement of testosterone and androstenedione by liquid chromatography-tandem mass spectrometry and analysis by receiver operator characteristic plots. European Journal of Endocrinology 162 611-615. (doi:10.1530/EJE-09-0741)

Bergan RC, Reed E, Myers CE, Headlee D, Brawley O, Cho HK, Figg WD, Tompkins A, Linehan WM, Kohler D et al. 1999 A phase II study of high-dose tamoxifen in patients with hormone-refractory prostate cancer. Clinical Cancer Research 5 2366-2373.

Bianco JJ, Handelsman DJ, Pedersen JS \& Risbridger GP 2002 Direct response of the murine prostate gland and seminal vesicles to estradiol. Endocrinology 143 4922-4933. (doi:10.1210/en.2002-220493)

Bianco JJ, McPherson SJ, Wang H, Prins GS \& Risbridger GP 2006 Transient neonatal estrogen exposure to estrogen-deficient mice (aromatase knockout) reduces prostate weight and induces inflammation in late life. American Journal of Pathology 168 1869-1878. (doi:10.2353/ ajpath.2006.050623)

Bonkhoff H \& Berges R 2009 The evolving role of oestrogens and their receptors in the development and progression of prostate cancer. European Urology 55 533-542. (doi:10.1016/j.eururo.2008.10.035) 
Bosland MC 2013 A perspective on the role of estrogen in hormoneinduced prostate carcinogenesis. Cancer Letters 334 28-33. (doi:10.1016/j.canlet.2012.08.027)

Bottner M, Thelen P \& Jarry H 2014 Estrogen receptor $\beta$ : tissue distribution and the still largely enigmatic physiological function. Journal of Steroid Biochemistry and Molecular Biology 139 245-51. (doi:10.1016/j.jsbmb. 2013.03.003)

Bouchal J, Santer FR, Hoschele PP, Tomastikova E, Neuwirt H \& Culig Z 2011 Transcriptional coactivators p300 and CBP stimulate estrogen receptor- $\beta$ signaling and regulate cellular events in prostate cancer. Prostate 71 431-437. (doi:10.1002/pros.21257)

Bubendorf L, Kononen J, Koivisto P, Schraml P, Moch H, Gasser TC, Willi N, Mihatsch MJ, Sauter G \& Kallioniemi OP 1999 Survey of gene amplifications during prostate cancer progression by high-throughout fluorescence in situ hybridization on tissue microarrays. Cancer Research 59 803-806.

Cai C \& Balk SP 2011 Intratumoral androgen biosynthesis in prostate cancer pathogenesis and response to therapy. Endocrine-Related Cancer 18 R175-R182. (doi:10.1530/ERC-10-0339)

Carroll JS, Liu XS, Brodsky AS, Li W, Meyer CA, Szary AJ, Eeckhoute J, Shao W, Hestermann EV, Geistlinger TR et al. 2005 Chromosome-wide mapping of estrogen receptor binding reveals long-range regulation requiring the forkhead protein FoxA1. Cell 122 33-43. (doi:10.1016/j.cell.2005. 05.008)

Carroll JS, Meyer CA, Song J, Li W, Geistlinger TR, Eeckhoute J, Brodsky AS, Keeton EK, Fertuck KC, Hall GF et al. 2006 Genome-wide analysis of estrogen receptor binding sites. Nature Genetics 38 1289-1297. (doi:10. 1038/ng1901)

Carruba G 2007 Estrogen and prostate cancer: an eclipsed truth in an androgen-dominated scenario. Journal of Cellular Biochemistry 102 899-911. (doi:10.1002/jcb.21529)

Celhay O, Yacoub M, Irani J, Dore B, Cussenot O \& Fromont G 2010 Expression of estrogen related proteins in hormone refractory prostate cancer: association with tumor progression. Journal of Urology 184 2172-2178. (doi:10.1016/j.juro.2010.06.089)

Centenera MM, Gillis JL, Hanson AR, Jindal S, Taylor RA, Risbridger GP, Sutherland PD, Scher HI, Raj GV, Knudsen KE et al. 2012 Evidence for efficacy of new Hsp90 inhibitors revealed by ex vivo culture of human prostate tumors. Clinical Cancer Research 18 3562-3570. (doi:10.1158/ 1078-0432.CCR-12-0782)

Chadha MK, Ashraf U, Lawrence D, Tian L, Levine E, Silliman C, Escott P, Payne V \& Trump DL 2008 Phase II study of fulvestrant (Faslodex) in castration resistant prostate cancer. Prostate 68 1461-1466. (doi:10.1002/pros.20813)

Chang WY \& Prins GS 1999 Estrogen receptor- $\beta$ : implications for the prostate gland. Prostate 40 115-124. (doi:10.1002/(SICI)10970045(19990701)40:2 < 115::AID-PROS7 > 3.0.CO;2-3)

Chantzi NI, Tiniakos DG, Palaiologou M, Goutas N, Filippidis T, Vassilaros SD, Dhimolea E, Mitsiou DJ \& Alexis MN 2013 Estrogen receptor $\beta 2$ is associated with poor prognosis in estrogen receptor $\alpha$-negative breast carcinoma. Journal of Cancer Research and Clinical Oncology 139 1489-1498. (doi:10.1007/s00432-013-1467-4)

Chen M, Ni J, Chang HC, Lin CY, Muyan M \& Yeh S 2009 CCDC62/ERAP75 functions as a coactivator to enhance estrogen receptor $\beta$-mediated transactivation and target gene expression in prostate cancer cells. Carcinogenesis 30 841-850. (doi:10.1093/carcin/bgn288)

Chmelar R, Buchanan G, Need EF, Tilley W \& Greenberg NM 2007 Androgen receptor coregulators and their involvement in the development and progression of prostate cancer. International Journal of Cancer 120 719-733. (doi:10.1002/ijc.22365)

Cotrim CZ, Fabris V, Doria ML, Lindberg K, Gustafsson JA, Amado F, Lanari C \& Helguero LA 2013 Estrogen receptor $\beta$ growth-inhibitory effects are repressed through activation of MAPK and PI3K signalling in mammary epithelial and breast cancer cells. Oncogene 32 2390-2402. (doi:10.1038/onc.2012.261)

Cussenot O, Azzouzi AR, Nicolaiew N, Fromont G, Mangin P, Cormier L, Fournier G, Valeri A, Larre S, Thibault F et al. 2007 Combination of polymorphisms from genes related to estrogen metabolism and risk of prostate cancers: the hidden face of estrogens. Journal of Clinical Oncology 25 3596-3602. (doi:10.1200/JCO.2007.11.0908)

Dehm SM, Schmidt LJ, Heemers HV, Vessella RL \& Tindall DJ 2008 Splicing of a novel androgen receptor exon generates a constitutively active androgen receptor that mediates prostate cancer therapy resistance. Cancer Research 68 5469-5477. (doi:10.1158/0008-5472.CAN-08-0594)

Dey P, Jonsson P, Hartman J, Williams C, Strom A \& Gustafsson JA 2012 Estrogen receptors $\beta 1$ and $\beta 2$ have opposing roles in regulating proliferation and bone metastasis genes in the prostate cancer cell line PC3. Molecular Endocrinology 26 1991-2003. (doi:10.1210/me.2012.1227)

Dey P, Barros RP, Warner M, Strom A \& Gustafsson JA 2013a Insight into the mechanisms of action of estrogen receptor $\beta$. Journal of Molecular Endocrinology 51 T61-T74. (doi:10.1530/JME-13-0150)

Dey P, Strom A \& Gustafsson JA $2013 b$ Estrogen receptor $\beta$ upregulates FOXO3a and causes induction of apoptosis through PUMA in prostate cancer. Oncogene. (doi:10.1038/onc.2013.384)

Ellem SJ \& Risbridger GP 2007 Treating prostate cancer: a rationale for targeting local oestrogens. Nature Reviews. Cancer 7 621-627. (doi:10.1038/nrc2174)

Ellem SJ, Schmitt JF, Pedersen JS, Frydenberg M \& Risbridger GP 2004 Local aromatase expression in human prostate is altered in malignancy. Journal of Clinical Endocrinology and Metabolism 89 2434-2441. (doi:10.1210/jc.2003-030933)

Enmark E, Pelto-Huikko M, Grandien K, Lagercrantz S, Lagercrantz J, Fried G, Nordenskjold M \& Gustafsson JA 1997 Human estrogen receptor $\beta$-gene structure, chromosomal localization, and expression pattern. Journal of Clinical Endocrinology and Metabolism 82 4258-4265.

Foryst-Ludwig A, Clemenz M, Hohmann S, Hartge M, Sprang C, Frost N, Krikov M, Bhanot S, Barros R, Morani A et al. 2008 Metabolic actions of estrogen receptor $\beta(E R \beta)$ are mediated by a negative cross-talk with PPAR $\gamma$. PLoS Genetics 4 e1000108. (doi:10.1371/journal.pgen.1000108)

Ganmaa D, Li XM, Qin LQ, Wang PY, Takeda M \& Sato A 2003 The experience of Japan as a clue to the etiology of testicular and prostatic cancers. Medical Hypotheses 60 724-730. (doi:10.1016/S03069877(03)00047-1)

Ghosh D, Griswold J, Erman M \& Pangborn W 2009 Structural basis for androgen specificity and oestrogen synthesis in human aromatase. Nature 457 219-223. (doi:10.1038/nature07614)

Grubisha MJ \& Defranco DB 2013 Local endocrine, paracrine and redox signaling networks impact estrogen and androgen crosstalk in the prostate cancer microenvironment. Steroids 78 538-541. (doi:10.1016/ j.steroids.2013.01.005)

Grubisha MJ, Cifuentes ME, Hammes SR \& Defranco DB 2012 A local paracrine and endocrine network involving TGF $\beta$, Cox-2, ROS, and estrogen receptor $\beta$ influences reactive stromal cell regulation of prostate cancer cell motility. Molecular Endocrinology 26 940-954. (doi:10.1210/me.2011-1371)

Guarino M, Rubino B \& Ballabio G 2007 The role of epithelialmesenchymal transition in cancer pathology. Pathology 39 305-318. (doi:10.1080/00313020701329914)

Haldosen LA, Zhao C \& Dahlman-Wright K 2014 Estrogen receptor $\beta$ in breast cancer. Molecular and Cellular Endocrinology 382 665-72. (doi:10.1016/j.mce.2013.08.005)

Hanahan D \& Weinberg RA 2011 Hallmarks of cancer: the next generation. Cell 144 646-674. (doi:10.1016/j.cell.2011.02.013)

Hanstein B, Liu H, Yancisin MC \& Brown M 1999 Functional analysis of a novel estrogen receptor- $\beta$ isoform. Molecular Endocrinology 13 129-137.

Harris HA 2007 Estrogen receptor- $\beta$ : recent lessons from in vivo studies. Molecular Endocrinology 21 1-13. (doi:10.1210/me.2005-0459)

Harris HA, Albert LM, Leathurby Y, Malamas MS, Mewshaw RE, Miller CP, Kharode YP, Marzolf J, Komm BS, Winneker RC et al. 2003 Evaluation of an estrogen receptor- $\beta$ agonist in animal models of human disease. Endocrinology 144 4241-4249. (doi:10.1210/en.2003-0550) http://erc.endocrinology-journals.org DOI: $10.1530 /$ ERC-13-0508
(C) 2014 Society for Endocrinology Printed in Great Britain 
Hartman J, Strom A \& Gustafsson JA 2012 Current concepts and significance of estrogen receptor $\beta$ in prostate cancer. Steroids $\mathbf{7 7}$ 1262-1266. (doi:10.1016/j.steroids.2012.07.002)

Hedelin M, Balter KA, Chang ET, Bellocco R, Klint A, Johansson JE, Wiklund F, Thellenberg-Karlsson C, Adami HO \& Gronberg H 2006 Dietary intake of phytoestrogens, estrogen receptor- $\beta$ polymorphisms and the risk of prostate cancer. Prostate 66 1512-1520. (doi:10.1002/ pros.20487)

Heidenreich A, Bellmunt J, Bolla M, Joniau S, Mason M, Matveev V, Mottet N, Schmid HP, van der Kwast T, Wiegel T et al. 2011 EAU guidelines on prostate cancer, Part 1: screening, diagnosis, and treatment of clinically localised disease. European Urology 59 61-71. (doi:10.1016/j.eururo. 2010.10.039)

Hickey TE \& Norman RJ 2010 Biomarkers: polycystic ovary syndrome: steroid assessment for diagnosis. Nature Reviews. Endocrinology 6 305-307. (doi:10.1038/nrendo.2010.68)

Holbeck S, Chang J, Best AM, Bookout AL, Mangelsdorf DJ \& Martinez ED 2010 Expression profiling of nuclear receptors in the NCI60 cancer cell panel reveals receptor-drug and receptor-gene interactions. Molecular Endocrinology 24 1287-1296. (doi:10.1210/me.2010-0040)

Hollier BG, Evans K \& Mani SA 2009 The epithelial-to-mesenchymal transition and cancer stem cells: a coalition against cancer therapies. Journal of Mammary Gland Biology \& Neoplasia 14 29-43. (doi:10.1007/ s10911-009-9110-3)

Holzbeierlein J, Lal P, LaTulippe E, Smith A, Satagopan J, Zhang L, Ryan C, Smith S, Scher H, Scardino P et al. 2004 Gene expression analysis of human prostate carcinoma during hormonal therapy identifies androgen-responsive genes and mechanisms of therapy resistance. American Journal of Pathology 164 217-227. (doi:10.1016/ S0002-9440(10)63112-4)

Hori S, Butler E \& McLoughlin J 2011 Prostate cancer and diet: food for thought? BJU International 107 1348-1359. (doi:10.1111/j.1464-410X. 2010.09897.x)

Horvath LG, Henshall SM, Lee CS, Head DR, Quinn DI, Makela S, Delprado W, Golovsky D, Brenner PC, O'Neill G et al. 2001 Frequent loss of estrogen receptor- $\beta$ expression in prostate cancer. Cancer Research 61 5331-5335.

Hu R, Lu C, Mostaghel EA, Yegnasubramanian S, Gurel M, Tannahill C, Edwards J, Isaacs WB, Nelson PS, Bluemn E et al. 2012 Distinct transcriptional programs mediated by the ligand-dependent full-length androgen receptor and its splice variants in castration-resistant prostate cancer. Cancer Research 72 3457-3462. (doi:10.1158/0008-5472. CAN-11-3892)

Huggins C 1943 Endocrine control of prostatic cancer. Science 97 541-544. (doi:10.1126/science.97.2529.541)

Huggins C \& Hodges CV 1972 Studies on prostatic cancer. I. The effect of castration, of estrogen and androgen injection on serum phosphatases in metastatic carcinoma of the prostate. CA: A Cancer Journal for Clinicians 22 232-240. (doi:10.3322/canjclin.22.4.232)

Hurtado A, Holmes KA, Ross-Innes CS, Schmidt D \& Carroll JS 2011 FOXA1 is a key determinant of estrogen receptor function and endocrine response. Nature Genetics 43 27-33. (doi:10.1038/ng.730)

Hussain S, Lawrence MG, Taylor RA, Lo CY, Frydenberg M, Ellem SJ, Furic L \& Risbridger GP 2012 Estrogen receptor $\beta$ activation impairs prostatic regeneration by inducing apoptosis in murine and human stem/progenitor enriched cell populations. PLOS ONE 7 e40732. (doi:10.1371/journal.pone.0040732)

Ishizaki F, Nishiyama T, Kawasaki T, Miyashiro Y, Hara N, Takizawa I, Naito M \& Takahashi K 2013 Androgen deprivation promotes intratumoral synthesis of dihydrotestosterone from androgen metabolites in prostate cancer. Scientific Reports 3 1528. (doi:10.1038/srep01528)

Jiang Y, Gong P, Madak-Erdogan Z, Martin T, Jeyakumar M, Carlson K, Khan I, Smillie TJ, Chittiboyina AG, Rotte SC et al. 2013 Mechanisms enforcing the estrogen receptor $\beta$ selectivity of botanical estrogens. FASEB Journal 27 4406-4418. (doi:10.1096/fj.13-234617)

http://erc.endocrinology-journals.org DOI: $10.1530 / E R C-13-0508$
(C) 2014 Society for Endocrinology Printed in Great Britain
Johnson BE, Whang-Peng J, Naylor SL, Zbar B, Brauch H, Lee E, Simmons A, Russell E, Nam MH \& Gazdar AF 1989 Retention of chromosome 3 in extrapulmonary small cell cancer shown by molecular and cytogenetic studies. Journal of the National Cancer Institute 81 1223-1228. (doi:10.1093/jnci/81.16.1223)

de Jong FH, Oishi K, Hayes RB, Bogdanowicz JF, Raatgever JW, van der Maas PJ, Yoshida O \& Schroeder FH 1991 Peripheral hormone levels in controls and patients with prostatic cancer or benign prostatic hyperplasia: results from the Dutch-Japanese case-control study. Cancer Research 51 3445-3450.

Kangas L 1990 Review of the pharmacological properties of toremifene. Journal of Steroid Biochemistry 36 191-195. (doi:10.1016/00224731(90)90003-B)

Kim IY, Kim BC, Seong DH, Lee DK, Seo JM, Hong YJ, Kim HT, Morton RA \& Kim SJ 2002a Raloxifene, a mixed estrogen agonist/antagonist, induces apoptosis in androgen-independent human prostate cancer cell lines. Cancer Research 62 5365-5369.

Kim IY, Seong DH, Kim BC, Lee DK, Remaley AT, Leach F, Morton RA \& Kim SJ $2002 b$ Raloxifene, a selective estrogen receptor modulator, induces apoptosis in androgen-responsive human prostate cancer cell line LNCaP through an androgen-independent pathway. Cancer Research 62 3649-3653.

Knudsen KE \& Penning TM 2010 Partners in crime: deregulation of AR activity and androgen synthesis in prostate cancer. Trends in Endocrinology and Metabolism 21 315-324. (doi:10.1016/j.tem.2010.01.002)

Kuiper GG, Enmark E, Pelto-Huikko M, Nilsson S \& Gustafsson JA 1996 Cloning of a novel receptor expressed in rat prostate and ovary. PNAS 93 5925-5930. (doi:10.1073/pnas.93.12.5925)

Kuiper GG, Lemmen JG, Carlsson B, Corton JC, Safe SH, van der Saag PT, van der Burg B \& Gustafsson JA 1998 Interaction of estrogenic chemicals and phytoestrogens with estrogen receptor $\beta$. Endocrinology 139 4252-4263.

Lai SL, Brauch H, Knutsen T, Johnson BE, Nau MM, Mitsudomi T, Tsai CM, Whang-Peng J, Zbar B, Kaye FJ et al. 1995 Molecular genetic characterization of neuroendocrine lung cancer cell lines. Anticancer Research 15 225-232.

Lamb AD, Massie CE \& Neal DE 2013 The transcriptional program of the androgen receptor (AR) in prostate cancer. BJU International. (doi:10.1111/bju.12415)

Langley RE, Cafferty FH, Alhasso AA, Rosen SD, Sundaram SK, Freeman SC, Pollock P, Jinks RC, Godsland IF, Kockelbergh R et al. 2013 Cardiovascular outcomes in patients with locally advanced and metastatic prostate cancer treated with luteinising-hormone-releasinghormone agonists or transdermal oestrogen: the randomised, phase 2 MRC PATCH trial (PR09). Lancet Oncology 14 306-316. (doi:10.1016/ S1470-2045(13)70025-1)

Lau KM, LaSpina M, Long J \& Ho SM 2000 Expression of estrogen receptor (ER)- $\alpha$ and ER- $\beta$ in normal and malignant prostatic epithelial cells: regulation by methylation and involvement in growth regulation. Cancer Research 60 3175-3182.

Lawrence MG, Taylor RA, Toivanen R, Pedersen J, Norden S, Pook DW, Frydenberg M, Papargiris MM, Niranjan B, Richards MG et al. 2013 A preclinical xenograft model of prostate cancer using human tumors. Nature Protocols 8 836-848. (doi:10.1038/nprot.2013.043)

Le TP, Sun M, Luo X, Kraus WL \& Greene GL 2013 Mapping ER $\beta$ genomic binding sites reveals unique genomic features and identifies EBF1 as an ER $\beta$ interactor. PLOS ONE 8 e71355. (doi:10.1371/journal.pone. 0071355)

Leav I, Lau KM, Adams JY, McNeal JE, Taplin ME, Wang J, Singh H \& Ho SM 2001 Comparative studies of the estrogen receptors $\beta$ and $\alpha$ and the androgen receptor in normal human prostate glands, dysplasia, and in primary and metastatic carcinoma. American Journal of Pathology 159 79-92. (doi:10.1016/S0002-9440(10)61676-8)

Leung YK, Gao Y, Lau KM, Zhang X \& Ho SM 2006a ICI 182,780-regulated gene expression in DU145 prostate cancer cells is mediated by estrogen 
receptor- $\beta / \mathrm{NF} \kappa \mathrm{B}$ crosstalk. Neoplasia 8 242-249. (doi:10.1593/ neo.05853)

Leung YK, Mak P, Hassan S \& Ho SM $2006 b$ Estrogen receptor (ER)- $\beta$ isoforms: a key to understanding ER- $\beta$ signaling. PNAS 103 13162-13167. (doi:10.1073/pnas.0605676103)

Leung YK, Lam HM, Wu S, Song D, Levin L, Cheng L, Wu CL \& Ho SM 2010 Estrogen receptor $\beta 2$ and $\beta 5$ are associated with poor prognosis in prostate cancer, and promote cancer cell migration and invasion. Endocrine-Related Cancer 17 675-689. (doi:10.1677/ERC-09-0294)

Li YM, Xu SC, Li J, Han KQ, Pi HF, Zheng L, Zuo GH, Huang XB, Li HY, Zhao HZ et al. 2013 Epithelial-mesenchymal transition markers expressed in circulating tumor cells in hepatocellular carcinoma patients with different stages of disease. Cell Death \& Disease 4 e831. (doi:10.1038/ cddis.2013.347)

Lumachi F, Luisetto G, Basso SM, Basso U, Brunello A \& Camozzi V 2011 Endocrine therapy of breast cancer. Current Medicinal Chemistry 18 513-522. (doi:10.2174/092986711794480177)

Madak-Erdogan Z, Charn TH, Jiang Y, Liu ET, Katzenellenbogen JA \& Katzenellenbogen BS 2013 Integrative genomics of gene and metabolic regulation by estrogen receptors $\alpha$ and $\beta$, and their coregulators. Molecular Systems Biology 9 676. (doi:10.1038/msb.2013.28)

Mak P, Chang C, Pursell B \& Mercurio AM 2013 Estrogen receptor $\beta$ sustains epithelial differentiation by regulating prolyl hydroxylase 2 transcription. PNAS 110 4708-4713. (doi:10.1073/pnas.1221654110)

Massie CE, Lynch A, Ramos-Montoya A, Boren J, Stark R, Fazli L, Warren A, Scott H, Madhu B, Sharma N et al. 2011 The androgen receptor fuels prostate cancer by regulating central metabolism and biosynthesis. EMBO Journal 30 2719-2733. (doi:10.1038/emboj.2011.158)

McPherson SJ, Ellem SJ \& Risbridger GP 2008 Estrogen-regulated development and differentiation of the prostate. Differentiation 76 660-670. (doi:10.1111/j.1432-0436.2008.00291.x)

McPherson SJ, Hussain S, Balanathan P, Hedwards SL, Niranjan B, Grant M, Chandrasiri UP, Toivanen R, Wang Y, Taylor RA et al. 2010 Estrogen receptor- $\beta$ activated apoptosis in benign hyperplasia and cancer of the prostate is androgen independent and TNF $\alpha$ mediated. PNAS 107 3123-3128. (doi:10.1073/pnas.0905524107)

Menasce LP, White GR, Harrison CJ \& Boyle JM 1993 Localization of the estrogen receptor locus (ESR) to chromosome $6 \mathrm{q} 25.1$ by FISH and a simple post-FISH banding technique. Genomics 17 263-265. (doi:10.1006/geno.1993.1320)

Merrimen JL, Jones G, Walker D, Leung CS, Kapusta LR \& Srigley JR 2009 Multifocal high grade prostatic intraepithelial neoplasia is a significant risk factor for prostatic adenocarcinoma. Journal of Urology 182 485-490 discussion 490. (doi:10.1016/j.juro.2009.04.016)

Mertz KD, Setlur SR, Dhanasekaran SM, Demichelis F, Perner S, Tomlins S, Tchinda J, Laxman B, Vessella RL, Beroukhim R et al. 2007 Molecular characterization of TMPRSS2-ERG gene fusion in the NCI-H660 prostate cancer cell line: a new perspective for an old model. Neoplasia 9 200-206. (doi:10.1593/neo.07103)

Messina M 2010 Insights gained from 20 years of soy research. Journal of Nutrition 140 2289S-2295S. (doi:10.3945/jn.110.124107)

Moore JT, McKee DD, Slentz-Kesler K, Moore LB, Jones SA, Horne EL, Su JL, Kliewer SA, Lehmann JM \& Willson TM 1998 Cloning and characterization of human estrogen receptor $\beta$ isoforms. Biochemical and Biophysical Research Communications 247 75-78. (doi:10.1006/ bbrc.1998.8738)

Morales A \& Pujari B 1975 The choice of estrogen preparations in the treatment of prostatic cancer. Canadian Medical Association Journal 113 865-867.

Mottet N, Bellmunt J, Bolla M, Joniau S, Mason M, Matveev V, Schmid HP, Van der Kwast T, Wiegel T, Zattoni F et al. 2011 EAU guidelines on prostate cancer. Part II: treatment of advanced, relapsing, and castration-resistant prostate cancer. European Urology 59 572-583. (doi:10.1016/j.eururo.2011.01.025)

Muthusamy S, Andersson S, Kim HJ, Butler R, Waage L, Bergerheim U \& Gustafsson JA 2011 Estrogen receptor $\beta$ and 17 $\beta$-hydroxysteroid dehydrogenase type 6 , a growth regulatory pathway that is lost in prostate cancer. PNAS 108 20090-20094. (doi:10.1073/pnas.1117772108)

Nakajima Y, Akaogi K, Suzuki T, Osakabe A, Yamaguchi C, Sunahara N, Ishida J, Kako K, Ogawa S, Fujimura T et al. 2011 Estrogen regulates tumor growth through a nonclassical pathway that includes the transcription factors ER $\beta$ and KLF5. Science Signaling 4 ra22. (doi:10.1126/scisignal.2001551)

Nakamura H, Wang Y, Xue H, Romanish MT, Mager DL, Helgason CD \& Wang Y 2013 Genistein versus ICI 182, 780: an ally or enemy in metastatic progression of prostate cancer. Prostate 73 1747-1760. (doi:10.1002/pros.22712)

Nelles JL, Hu WY \& Prins GS 2011 Estrogen action and prostate cancer. Expert Review of Endocrinology \& Metabolism 6 437-451. (doi:10.1586/ eem.11.20)

Nelson WG, De Marzo AM \& Isaacs WB 2003 Prostate cancer. New England Journal of Medicine 349 366-381. (doi:10.1056/NEJMra021562)

Oliveira AG, Coelho PH, Guedes FD, Mahecha GA, Hess RA \& Oliveira CA

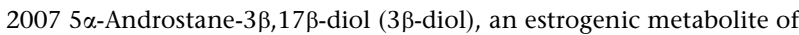
$5 \alpha$-dihydrotestosterone, is a potent modulator of estrogen receptor ER $\beta$ expression in the ventral prostrate of adult rats. Steroids 72 914-922. (doi:10.1016/j.steroids.2007.08.001)

Pinzone JJ, Stevenson H, Strobl JS \& Berg PE 2004 Molecular and cellular determinants of estrogen receptor $\alpha$ expression. Molecular and Cellular Biology 24 4605-4612. (doi:10.1128/MCB.24.11.4605-4612.2004)

Price D, Stein B, Sieber P, Tutrone R, Bailen J, Goluboff E, Burzon D, Bostwick D \& Steiner M 2006 Toremifene for the prevention of prostate cancer in men with high grade prostatic intraepithelial neoplasia: results of a double-blind, placebo controlled, phase IIB clinical trial. Journal of Urology 176 965-970 discussion 970-961. (doi:10.1016/j.juro. 2006.04.011)

Prins GS \& Birch L 1997 Neonatal estrogen exposure up-regulates estrogen receptor expression in the developing and adult rat prostate lobes. Endocrinology 138 1801-1809.

Prins GS \& Korach KS 2008 The role of estrogens and estrogen receptors in normal prostate growth and disease. Steroids 73 233-244. (doi:10.1016/ j.steroids.2007.10.013)

Prins GS, Huang L, Birch L \& Pu Y 2006 The role of estrogens in normal and abnormal development of the prostate gland. Annals of the New York Academy of Sciences 1089 1-13. (doi:10.1196/annals.1386.009)

Prins GS, Birch L, Tang WY \& Ho SM 2007 Developmental estrogen exposures predispose to prostate carcinogenesis with aging. Reproductive Toxicology 23 374-382. (doi:10.1016/j.reprotox.2006.10.001)

Qu X, Randhawa G, Friedman C, Kurland BF, Glaskova L, Coleman I, Mostaghel E, Higano CS, Porter C, Vessella R et al. 2013 A three-marker FISH panel detects more genetic aberrations of, and in castrationresistant or metastatic prostate cancers than in primary prostate tumors. PLOS ONE 8 e74671. (doi:10.1371/journal.pone.0074671)

Razzak M 2013 Prostate cancer: not guilty-TMPRSS2-ERG does not sensitize cells to radiation. Nature Reviews. Urology 10 556. (doi:10.1038/nrurol. 2013.188)

Reiter E, Gerster P \& Jungbauer A 2011 Red clover and soy isoflavones - an in vitro safety assessment. Gynecological Endocrinology 27 1037-1042. (doi:10.3109/09513590.2011.588743)

Ricke WA, McPherson SJ, Bianco JJ, Cunha GR, Wang Y \& Risbridger GP 2008 Prostatic hormonal carcinogenesis is mediated by in situ estrogen production and estrogen receptor $\alpha$ signaling. FASEB Journal 22 1512-1520. (doi:10.1096/fj.07-9526com)

Risbridger GP, Ellem SJ \& McPherson SJ 2007 Estrogen action on the prostate gland: a critical mix of endocrine and paracrine signaling. Journal of Molecular Endocrinology 39 183-188. (doi:10.1677/JME-07-0053)

Robinson JL, Macarthur S, Ross-Innes CS, Tilley WD, Neal DE, Mills IG \& Carroll JS 2011 Androgen receptor driven transcription in molecular apocrine breast cancer is mediated by FoxA1. EMBO Journal 30 3019-3027. (doi:10.1038/emboj.2011.216)

Rody A, Holtrich U, Solbach C, Kourtis K, von Minckwitz G, Engels K, Kissler S, Gatje R, Karn T \& Kaufmann M 2005 Methylation of estrogen

Published by Bioscientifica Ltd. 
receptor $\beta$ promoter correlates with loss of ER- $\beta$ expression in mammary carcinoma and is an early indication marker in premalignant lesions. Endocrine-Related Cancer 12 903-916. (doi:10.1677/erc.1.01088)

Rohlff C, Blagosklonny MV, Kyle E, Kesari A, Kim IY, Zelner DJ, Hakim F, Trepel J \& Bergan RC 1998 Prostate cancer cell growth inhibition by tamoxifen is associated with inhibition of protein kinase $\mathrm{C}$ and induction of p21(waf1/cip1). Prostate 37 51-59. (doi:10.1002/ (SICI)1097-0045(19980915)37:1 < 51::AID-PROS8 > 3.0.CO;2-B)

Rohrmann S, Nelson WG, Rifai N, Brown TR, Dobs A, Kanarek N, Yager JD $\&$ Platz EA 2007 Serum estrogen, but not testosterone, levels differ between black and white men in a nationally representative sample of Americans. Journal of Clinical Endocrinology and Metabolism 92 2519-2525. (doi:10.1210/jc.2007-0028)

Ross RK, Bernstein L, Lobo RA, Shimizu H, Stanczyk FZ, Pike MC \& Henderson BE 19925 - $\alpha$-reductase activity and risk of prostate cancer among Japanese and US white and black males. Lancet 339 887-889. (doi:10.1016/0140-6736(92)90927-U)

Rossi V, Bellastella G, De Rosa C, Abbondanza C, Visconti D, Maione L, Chieffi P, Della Ragione F, Prezioso D, De Bellis A et al. 2011 Raloxifene induces cell death and inhibits proliferation through multiple signaling pathways in prostate cancer cells expressing different levels of estrogen receptor $\alpha$ and $\beta$. Journal of Cellular Physiology 226 1334-1339. (doi:10.1002/jcp.22461)

Roy S, Chakravarty D, Cortez V, De Mukhopadhyay K, Bandyopadhyay A, Ahn JM, Raj GV, Tekmal RR, Sun L \& Vadlamudi RK 2012 Significance of PELP1 in ER-negative breast cancer metastasis. Molecular Cancer Research 10 25-33. (doi:10.1158/1541-7786.MCR-11-0456)

Ruizeveld de Winter JA, Trapman J, Vermey M, Mulder E, Zegers ND \& van der Kwast TH 1991 Androgen receptor expression in human tissues: an immunohistochemical study. Journal of Histochemistry and Cytochemistry 39 927-936. (doi:10.1177/39.7.1865110)

Sahu B, Laakso M, Ovaska K, Mirtti T, Lundin J, Rannikko A, Sankila A Turunen JP, Lundin M, Konsti J et al. 2011 Dual role of FoxA1 in androgen receptor binding to chromatin, androgen signalling and prostate cancer. EMBO Journal 30 3962-3976. (doi:10.1038/emboj. 2011.328)

Santen RJ, Santner SJ, Pauley RJ, Tait L, Kaseta J, Demers LM, Hamilton C, Yue W \& Wang JP 1997 Estrogen production via the aromatase enzyme in breast carcinoma: which cell type is responsible? Journal of Steroid Biochemistry and Molecular Biology 61 267-271. (doi:10.1016/ S0960-0760(97)80022-2)

Scher HI, Buchanan G, Gerald W, Butler LM \& Tilley WD 2004 Targeting the androgen receptor: improving outcomes for castration-resistant prostate cancer. Endocrine-Related Cancer 11 459-476. (doi:10.1677/ erc.1.00525)

Setlur SR, Mertz KD, Hoshida Y, Demichelis F, Lupien M, Perner S, Sboner A, Pawitan Y, Andren O, Johnson LA et al. 2008 Estrogen-dependent signaling in a molecularly distinct subclass of aggressive prostate cancer. Journal of the National Cancer Institute 100 815-825. (doi:10.1093/jnci/djn150)

Shaaban AM, O'Neill PA, Davies MP, Sibson R, West CR, Smith PH \& Foster CS 2003 Declining estrogen receptor- $\beta$ expression defines malignant progression of human breast neoplasia. American Journal of Surgical Pathology 27 1502-1512. (doi:10.1097/00000478-200312000-00002)

Sharma NL, Massie CE, Ramos-Montoya A, Zecchini V, Scott HE, Lamb AD, MacArthur S, Stark R, Warren AY, Mills IG et al. 2013 The androgen receptor induces a distinct transcriptional program in castrationresistant prostate cancer in man. Cancer Cell 23 35-47. (doi:10.1016/ j.ccr.2012.11.010)

Shen JC, Klein RD, Wei Q, Guan Y, Contois JH, Wang TT, Chang S \& Hursting SD 2000 Low-dose genistein induces cyclin-dependent kinase inhibitors and G(1) cell-cycle arrest in human prostate cancer cells. Molecular Carcinogenesis 29 92-102. (doi:10.1002/10982744(200010)29:2<92::AID-MC6>3.0.CO;2-Q)
Shozu M, Zhao Y \& Simpson ER 2000 TGF- $\beta 1$ stimulates expression of the aromatase (CYP19) gene in human osteoblast-like cells and THP-1 cells. Molecular and Cellular Endocrinology 160 123-133. (doi:10.1016/ S0303-7207(99)00233-6)

Sissung TM, Danesi R, Kirkland CT, Baum CE, Ockers SB, Stein EV, Venzon D, Price DK \& Figg WD 2011 Estrogen receptor $\alpha$ and aromatase polymorphisms affect risk, prognosis, and therapeutic outcome in men with castration-resistant prostate cancer treated with docetaxel-based therapy. Journal of Clinical Endocrinology and Metabolism 96 E368-E372. (doi:10.1210/jc.2010-2070)

Skliris GP, Parkes AT, Limer JL, Burdall SE, Carder PJ \& Speirs V 2002 Evaluation of seven oestrogen receptor $\beta$ antibodies for immunohistochemistry, western blotting, and flow cytometry in human breast tissue. Journal of Pathology 197 155-162. (doi:10.1002/path.1077)

Stener-Victorin E, Holm G, Labrie F, Nilsson L, Janson PO \& Ohlsson C 2010 Are there any sensitive and specific sex steroid markers for polycystic ovary syndrome? Journal of Clinical Endocrinology and Metabolism 95 810-819. (doi:10.1210/jc.2009-1908)

Stettner M, Kaulfuss S, Burfeind P, Schweyer S, Strauss A, Ringert RH \& Thelen P 2007 The relevance of estrogen receptor- $\beta$ expression to the antiproliferative effects observed with histone deacetylase inhibitors and phytoestrogens in prostate cancer treatment. Molecular Cancer Therapeutics 6 2626-2633. (doi:10.1158/1535-7163.MCT-07-0197)

Subbaramaiah K, Howe LR, Bhardwaj P, Du B, Gravaghi C, Yantiss RK, Zhou XK, Blaho VA, Hla T, Yang P et al. 2011 Obesity is associated with inflammation and elevated aromatase expression in the mouse mammary gland. Cancer Prevention Research 4 329-346. (doi:10.1158/ 1940-6207.CAPR-10-0381)

Suzuki F, Akahira J, Miura I, Suzuki T, Ito K, Hayashi S, Sasano H \& Yaegashi N 2008 Loss of estrogen receptor $\beta$ isoform expression and its correlation with aberrant DNA methylation of the 5 '-untranslated region in human epithelial ovarian carcinoma. Cancer Science 99 2365-2372. (doi:10.1111/j.1349-7006.2008.00988.x)

Thelen P, Scharf JG, Burfeind P, Hemmerlein B, Wuttke W, Spengler B, Christoffel V, Ringert RH \& Seidlova-Wuttke D 2005 Tectorigenin and other phytochemicals extracted from leopard lily Belamcanda chinensis affect new and established targets for therapies in prostate cancer. Carcinogenesis 26 1360-1367. (doi:10.1093/carcin/bgi092)

Thelen P, Peter T, Hunermund A, Kaulfuss S, Seidlova-Wuttke D, Wuttke W, Ringert RH \& Seseke F 2007 Phytoestrogens from Belamcanda chinensis regulate the expression of steroid receptors and related cofactors in LNCaP prostate cancer cells. BJU International 100 199-203. (doi:10.1111/j.1464-410X.2007.06924.x)

Thelen P, Wuttke W \& Seidlova-Wuttke D 2014 Phytoestrogens selective for the estrogen receptor $\beta$ exert anti-androgenic effects in castration resistant prostate cancer. Journal of Steroid Biochemistry and Molecular Biology 139 290-3. (doi:10.1016/j.jsbmb.2013.06.009)

Tilley WD, Horsfall DJ, McGee MA, Henderson DW \& Marshall VR 1985 Distribution of oestrogen and androgen receptors between the stroma and epithelium of the guinea-pig prostate. Journal of Steroid Biochemistry 22 713-719. (doi:10.1016/0022-4731(85)90276-6)

Vadlamudi RK, Wang RA, Mazumdar A, Kim Y, Shin J, Sahin A \& Kumar R 2001 Molecular cloning and characterization of PELP1, a novel human coregulator of estrogen receptor $\alpha$. Journal of Biological Chemistry 276 38272-38279.

Veldscholte J, Ris-Stalpers C, Kuiper GG, Jenster G, Berrevoets C, Claassen E, van Rooij HC, Trapman J, Brinkmann AO \& Mulder E 1990 A mutation in the ligand binding domain of the androgen receptor of human LNCaP cells affects steroid binding characteristics and response to anti-androgens. Biochemical and Biophysical Research Communications 173 534-540. (doi:10.1016/S0006-291X(05)80067-1)

Vermeulen A, Kaufman JM, Goemaere S \& van Pottelberg I 2002 Estradiol in elderly men. Aging Male 5 98-102.

Waltering KK, Urbanucci A \& Visakorpi T 2012 Androgen receptor (AR) aberrations in castration-resistant prostate cancer. Molecular and Cellular Endocrinology 360 38-43. (doi:10.1016/j.mce.2011.12.019) 
Wang Q, Li W, Liu XS, Carroll JS, Janne OA, Keeton EK, Chinnaiyan AM, Pienta KJ \& Brown M 2007 A hierarchical network of transcription factors governs androgen receptor-dependent prostate cancer growth. Molecular Cell 27 380-392. (doi:10.1016/j.molcel.2007.05.041)

Wang Q, Li W, Zhang Y, Yuan X, Xu K, Yu J, Chen Z, Beroukhim R, Wang H, Lupien $\mathrm{M}$ et al. 2009 Androgen receptor regulates a distinct transcription program in androgen-independent prostate cancer. Cell 138 245-256. (doi:10.1016/j.cell.2009.04.056)

Wang D, Garcia-Bassets I, Benner C, Li W, Su X, Zhou Y, Qiu J, Liu W, Kaikkonen MU, Ohgi KA et al. 2011 Reprogramming transcription by distinct classes of enhancers functionally defined by eRNA. Nature $\mathbf{4 7 4}$ 390-394. (doi:10.1038/nature10006)

Weitsman GE, Skliris G, Ung K, Peng B, Younes M, Watson PH \& Murphy LC 2006 Assessment of multiple different estrogen receptor- $\beta$ antibodies for their ability to immunoprecipitate under chromatin immunoprecipitation conditions. Breast Cancer Research and Treatment 100 23-31. (doi:10.1007/s10549-006-9229-5)

Wernert N, Gerdes J, Loy V, Seitz G, Scherr O \& Dhom G 1988 Investigations of the estrogen (ER-ICA-test) and the progesterone receptor in the prostate and prostatic carcinoma on immunohistochemical basis. Virchows Archiv. A, Pathological Anatomy and Histopathology 412 387-391. (doi:10.1007/BF00750267)

Wu SL, Jones E, Gulley JL, Arlen PM, Chen CC, Figg WD \& Dahut WL 2007 Routine interval computed tomography to detect new soft-tissue disease might be unnecessary in patients with androgen-independent prostate cancer and metastasis only to bone. BJU International 99 525-528. (doi:10.1111/j.1464-410X.2006.06654.x)

Wuttke W, Jarry H, Westphalen S, Christoffel V \& Seidlova-Wuttke D 2002 Phytoestrogens for hormone replacement therapy? Journal of Steroid Biochemistry and Molecular Biology 83 133-147. (doi:10.1016/ S0960-0760(02)00259-5)

Yang L, Ravindranathan P, Ramanan M, Kapur P, Hammes SR, Hsieh JT \& Raj GV 2012 Central role for PELP1 in nonandrogenic activation of the androgen receptor in prostate cancer. Molecular Endocrinology 26 550-561. (doi:10.1210/me.2011-1101)
Yao S, Till C, Kristal AR, Goodman PJ, Hsing AW, Tangen CM, Platz EA, Stanczyk FZ, Reichardt JK, Tang L et al. 2011 Serum estrogen levels and prostate cancer risk in the prostate cancer prevention trial: a nested case-control study. Cancer Causes \& Control 22 1121-1131. (doi:10.1007/s10552-011-9787-7)

Zellweger T, Sturm S, Rey S, Zlobec I, Gsponer JR, Rentsch CA, Terracciano LM, Bachmann A, Bubendorf L \& Ruiz C 2013 Estrogen receptor $\beta$ expression and androgen receptor phosphorylation correlate with a poor clinical outcome in hormone-naive prostate cancer and are elevated in castration-resistant disease. Endocrine-Related Cancer 20 403-413. (doi:10.1530/ERC-12-0402)

Zhao Y, Agarwal VR, Mendelson CR \& Simpson ER 1997 Transcriptional regulation of CYP19 gene (aromatase) expression in adipose stromal cells in primary culture. Journal of Steroid Biochemistry and Molecular Biology 61 203-210. (doi:10.1016/S0960-0760(97)80013-1)

Zhao C, Lam EW, Sunters A, Enmark E, De Bella MT, Coombes RC, Gustafsson JA \& Dahlman-Wright K 2003 Expression of estrogen receptor $\beta$ isoforms in normal breast epithelial cells and breast cancer: regulation by methylation. Oncogene 22 7600-7606. (doi:10.1038/ sj.onc.1207100)

Zhao C, Matthews J, Tujague M, Wan J, Strom A, Toresson G, Lam EW, Cheng G, Gustafsson JA \& Dahlman-Wright K 2007 Estrogen receptor $\beta 2$ negatively regulates the transactivation of estrogen receptor $\alpha$ in human breast cancer cells. Cancer Research 67 3955-3962. (doi:10.1158/ 0008-5472.CAN-06-3505)

Zhao C, Gao H, Liu Y, Papoutsi Z, Jaffrey S, Gustafsson JA \& DahlmanWright K 2010 Genome-wide mapping of estrogen receptor- $\beta$-binding regions reveals extensive cross-talk with transcription factor activator protein-1. Cancer Research 70 5174-5183. (doi:10.1158/0008-5472. CAN-09-4407)

Zhu X, Leav I, Leung YK, Wu M, Liu Q, Gao Y, McNeal JE \& Ho SM 2004 Dynamic regulation of estrogen receptor- $\beta$ expression by DNA methylation during prostate cancer development and metastasis. American Journal of Pathology 164 2003-2012. (doi:10.1016/ S0002-9440(10)63760-1)

Received in final form 31 December 2013

Accepted 6 January 2014

Made available online as an Accepted Preprint

8 January 2014 http://erc.endocrinology-journals.org DOI: 10.1530/ERC-13-0508
(C) 2014 Society for Endocrinology Printed in Great Britain 